\title{
Reform and Practice of Improving Graduation Design in Applied Undergraduate Colleges and Universities
}

\author{
Yan Wei \\ School of Computer Science and Engineering, Changshu Institute of Technology, Changshu, 215500, China \\ 120570473@qq.com
}

Keywords: graduation project; graduation thesis; practical teaching

\begin{abstract}
Based on the quality problems in the graduation design (thesis) of graduation under the new situation, this paper introduces the measures to improve the quality of graduation design (thesis) from the perspective of management in Changshu Institute of Technology.
\end{abstract}

\section{Main Factors for Quality of Graduation Design (Paper)}

In recent years, the quality of graduation design (paper) has been in decline because of various reasons $^{[2-3]}$. It has three principally aspects as follows.

\subsection{Inappropriate Topic}

The first step of graduation design (paper) is topic selection. An appropriate topic and the definite design contents are the premise of improving the quality of graduation design (paper) ${ }^{[4]}$. From the selected topics of graduation design (paper) of graduates of all previous years, there are mainly problems in the following aspects. Firstly, the selected topic is not kept in line with the major training direction. For example, some internet of things majors of computer science department chose to study the software development or digital media. The graduation design (paper) is disconnected from the goal of major training. Secondly, the topic difficulty exceeds the requirements of undergraduate train scheme. The difficulty of some selected topics are far out of the students' reach. So the effect of comprehensive practice can not be obtained. Thirdly, the selected topics of individual student such as file management system and book lending system has a higher repetition rate compared to that of all previous years. These similar topics are not conductive to the training of students on their innovation ability. Fourthly, theoretical researches occupy a certain proportion of the graduation design (paper). For example, the development research work of graduation design (paper) is completed by some students, but which can not be really applied in practice. This is disconnected from the goal of cultivating the applied talents.

\subsection{Students' Own Attention}

It is the main reason for decline in the quality of graduation design (paper) that students have not paid enough attention to their designs (papers). It is mainly reflected as follows: Firstly, the time-based conflict of employment and postgraduate entrance exam makes the students can not concentrate on their graduation designs (papers). Secondly, with the fluke mind, some students complete their graduation designs (papers) by searching, modifying and copying the completed papers in the internet. From the test results of PMLC of China national knowledge internet, the repetition rate of partial students' graduation designs (papers) is higher than $30 \%$ in each year. Paper plagiarism has become the biggest barrier for the evolution type cultivation model of academic paper writing, and which has seriously affected the quality of graduation design (paper) ${ }^{[5-6]}$.

\subsection{Guide Teachers' Guidance to the Graduation Design (Paper)}

The guide teachers are an important factor for the quality of graduation design (paper) ${ }^{[7]}$. At presently, due to a lot of teaching and scientific research tasks, a few guide teachers without a strong sense of responsibility only spend the minimized time on providing guidance for the students' graduation designs (papers). It is specifically reflected as follows: non-strictness with the topic 
selection report and thesis proposal, careless and direct pass in system, no timely guidance and correction for the problems such as no data support for the argument, unreasonable structure and unclear arrangement existed during the intermediate inspection and paper finalization. The comments of guide teachers are often simple and formal such as "Yes" or "Pass", and which severely weaken the guidance of guide teachers.

\section{Establishment of Perfect Management and Supervision System for Graduation Design (Paper)}

To solve the above general problems, General Office of Ministry of Education specially released "a notice about strengthening the work of graduation design (paper) for colleges and universities" ${ }^{[8]}$. Based on the characteristics of computer specialty, combined with the work regulations of graduation design (paper) in our university, we establish and perfect a management mechanism for graduation design (paper). the practice shows that this mechanism has obvious innovation and maneuverability.

\subsection{System and Procedure Management for Graduation Design (Paper) Work}

Organization management. To well do the organization management work, we firmly implement the three-level management system of dean's office, institute and department. Among them, the dean's office is responsible for the macro management and guidance for graduation design (paper) work in the university. The leading groups that headed up in the deans should be established in the second institutes for arranging and implementing the work plans and implementation plans. The steering groups that headed up in the department heads should be established in the departments for implementing the work requirements and regulations of college and institute.

System management. The school established the work regulations for graduation design (paper) of Changshu Institute of Technology, and in which, the organization and management of graduation design (paper) work, topic selection work, students' requirements, guidance work, defense work, the work of assessment of theses and recommending the excellent, and quality monitoring and inspection have been specified. On this basis, the institute and departments well made the work arrangement combined with their own situations.

Procedure management. In late October each year, the dean's office releases a notice about starting the new session of graduation design (paper) work to specify each of the regulations and the related matters such as the intelligent management system maintenance for graduation design (paper), the requirements for topic selection work and the graduation design (paper) work scheduling. According to the requirements of the dean's office, combined with the actual situations of each institute, the second institutes make each teacher know each of regulation by holding a meeting on Wednesday afternoon. For the new teachers unfamiliar with the intelligent management system for graduation design (paper), the point-to-point or centralized training shall be provided for them by the experts and teachers. With a clear division of rights and responsibilities, the whole work linked together is carried out in order.

\subsection{Scientific Topic Is the Foundation of Topic Selection Work of Graduation Design (Paper)}

The topic selection for graduation design (paper) should not only meet the requirements of the goal of applied talents cultivation, but also be scientific. It is the foundation of improving the quality of graduation design (paper) to reasonably subdivide the requirements of topic selection ${ }^{[9]}$. On this basis, the department of computer science puts forward the following requirements:

In the topic selection stage, the institute should instruct the headteachers, guide teachers and students to prepare for the topic selection work of graduation design (paper) combined with the work requirements of the dean's office. It is specifically reflected as follows. Firstly, the students should be encouraged to actively contact their guide teachers for two-way choice of the topics. Secondly, the guide teachers should make a accurate estimation for the final selected topic according to each student's characteristics. In addition, the selected topic should meet the goal of cultivating applied talents in depth, difficulty and workload. Thirdly, in the topic selection stage, the 
head teacher is a coordinator between the students and the guide teachers as the communicative bridge.

Table 1 Topic Selection Requirements of Graduation Design (Paper)

\begin{tabular}{|c|c|}
\hline No. & Topic Selection Requirements of Graduation Design (Paper) \\
\hline A & $\begin{array}{l}\text { The knowledge and technologies related to the topic should be within their } \\
\text { specific fields. The selected topic should be conductive to students in } \\
\text { innovation, expanding or realization of research and penetration of } \\
\text { interdisciplinary course. }\end{array}$ \\
\hline $\mathrm{B}$ & $\begin{array}{l}\text { The topic should be selected from the construction of social economy and } \\
\text { the practical problems, and it should reflect the basic requirements of the } \\
\text { goal of students cultivation. Under teachers' guidance, students can directly } \\
\text { carry out or participate in the practical scientific and technical topics } \\
\text { selection, avoid the false topics to improve their abilities to apply knowledge } \\
\text { and solve practical problems. }\end{array}$ \\
\hline $\mathrm{C}$ & $\begin{array}{l}\text { The difficulty and workload of the selected topic should be appropriate to } \\
\text { ensure that students can complete their graduation designs (papers) or } \\
\text { acquire the phase fruits within the required time. }\end{array}$ \\
\hline $\mathrm{D}$ & $\begin{array}{l}\text { For the big topic multiple students bear or participated in, its small topics } \\
\text { should be clearly subdivided, and each small topic should has the specific } \\
\text { technical specifications and content requirements. }\end{array}$ \\
\hline E & $\begin{array}{l}\text { Topic selection should achieve the goal of comprehensive training. It should } \\
\text { avoid some problems such as over-professional topic selection range, } \\
\text { over-narrow topic selection range or being beyond the bounds of the basic } \\
\text { knowledge of this major. }\end{array}$ \\
\hline F & $\begin{array}{l}\text { Each department should strictly make checks on the level of topic } \\
\text { examination according to the principle of one student - one topic. }\end{array}$ \\
\hline G & $\begin{array}{l}\text { The double teacher system should be adopted for the students who hire the } \\
\text { outside-school guide teachers for their graduation designs (papers). The } \\
\text { school teachers should be responsible for the quality of students' graduation } \\
\text { designs (papers). In principle, the design or paper topics of students in } \\
\text { practice of cooperation between school and enterprise should be selected } \\
\text { from the enterprise, and the students can continue their graduation designs } \\
\text { (papers) work only when their selected topics are approved by the steering } \\
\text { group for graduation design (paper) work. }\end{array}$ \\
\hline $\mathrm{H}$ & $\begin{array}{l}\text { To ensure continual renewal of the topics of graduation design (paper) and } \\
\text { avoid students' acts of plagiarism, it is required that all students' design } \\
\text { (paper) topics should be non-repetitive for three years in a row. }\end{array}$ \\
\hline
\end{tabular}

\subsection{Strengthening the Team Construction of Guide Teachers of Graduation Design (Paper)}

To ensure the quality of graduation design (paper), it is very necessary to establish a teacher team with high quality, excellent teaching skill, strong scientific research capacity and reasonable professional title structure.

The right concept should be set up to be responsible for the students. In accordance with the notice about working well the pre-service training work for teachers of colleges and universities in 2017 (SuJiaoRen No.10, 2017), the school should conduct the pre-service training for the new teachers. The training contents include the teachers' professional ethical code, education policy, theory of modern education, the basic skills of education and teaching, etc. The training can be realized using a method of combing online training and offline training. The contents such as teaching style, teaching, scientific research and modern education technology are emphasized to strengthen the pre-service training for the new teachers ${ }^{[10]}$.

The retired teachers with middle or high professional titles or rich experience in teaching should 
be mainly introduced into the teach team to help the new teachers improve the quality of graduation design (paper).

The qualification examination for guide teachers should be strengthened. In principle, the guide teachers for graduation design (paper) should be the teachers and professionals with mediate or high professional titles. For the teachers with guidance level for graduation design (paper), but without the above professional titles, they also can organize a team to guide students' graduation design (paper) after obtaining the approval of institute dean.

\subsection{Strengthening the Process Management and Monitoring of Graduation Design (Paper)}

The teaching process management for graduation design (paper) is a dynamic process. The management and monitoring for process can help to find problems, feedback information and adjust \& control in time ${ }^{[11]}$. For example, combined with the work scheduling of graduation design (paper), the leading group for graduation design (paper) of the second institutes should carry out a thorough inspection of the prep work of graduation design (paper) in the institute. The inspection objects include the arguments table for topic selection of guide teachers, the thesis proposal of students, the process records of graduation design and the guidance of teachers. Aiming at the existed problems, the department head firstly rejects the graduation design (paper) and provides his or her comments. Then the institute proposes the rectification requirements for the existed problems by timely holding the steering meeting and feeding the relevant information. Many strict inspections strongly guarantee the quality of process management and monitoring in this stage.

\subsection{Being Strict With the Graduation Design (Paper) Defense and Achievement Assessment}

The defense \& achievement assessment is the last critical link of graduation design (paper). The scientificity, strictness and justice of defense strongly guide the graduation design (paper) ${ }^{\text {[12-13] }}$. In accordance with requirements of the dean's office, the institutes establish the committee of graduation design (paper) defense responsible for the appraisal of graduation design (paper) and the defense arrangement. The appraisal teachers for graduation design (paper) are determined by the committee of replying. In the appraisal process of graduation design (paper), the teachers are required to carry out the comprehensive and strict viewing and scoring according to the academic level of graduation design (paper), the research method of graduation design (paper), the standardization of graduation design (paper) and the achievement of graduation design (paper). The committee of replying will examine students' replying qualification for graduation design (paper). Before the defence, a training work meeting of the committee members should be held, and in which the arrangement and procedure of the defence should be posted on the site to well prepare for the defence and ensure that the defence can be successfully processed. After completion of the work of graduation design (paper) defense, the achievement assessment of graduation design (paper) is carried out by the committee of replying. At the same time, the institute's excellent graduation design (paper) should be selected and recommended as school's excellent graduation design (paper).

\subsection{Carrying Out the Special Examination Work for the Quality and Management of Graduation Design (Paper)}

To further improve the quality of graduation design (paper) and standardize the management work of graduation design (paper), it is very necessary to carry out a special examination of the quality and management of graduation design (paper). The examination work can be divided into three stages. In the first stage, after completion of the defense, the dean of the second institute should write the work summary and quality analysis report for graduation design (paper) in time. In the second stage, the graduation designs (papers) of second institutes will be evaluated by the supervisors arranged by the school. In the third stage, the school's specialist group will randomly select some designs (papers) for quality inspection from all graduation designs (papers) of the institutes and provide the site feed back. Lastly, the quality management office will summarize, feed back and announce the inspection result. 


\section{Conclusion}

The intelligent management system of graduation design (paper) was used in Changshu Institute of Technology in 2013 (http://bylw.cslg.cn). During the period, the service conditions and amendment opinions of the second institutes were recorded and fed by the dean's office in time. At present, the system is continually being improved, and the functional operation has become more and more humanitarian. The practice has showed that the management system and monitoring for graduation design (paper) can remarkably promote improvement of the quality of graduation design (paper). In each year, the graduation design (paper) guided by the teacher team of department of computer science can be selected the important supporting group topic of school level. Many teachers have been chosen as merit teachers for graduation design (paper) of colleges and universities in Jiangsu province, and due to the graduation designs (papers) with high quality and scientific research value, some students were admitted into Nanjing University and Peking University in the reexamination stage of postgraduate entrance examination.

It is the starting point and focus of graduation design (paper) to cultivate the students' ability of engineering practice ${ }^{[14]}$. The national education reform and development of long-term planning programs (2010-2020) pointed out that, "for deepening the reform of the educational system, the key is to renew education idea, the core is to reform the talents training system, the goal is to improve the cultivating level of talents”. Therefore, in front of the new situations and problems, it needs each teaching management personnel to unceasingly practice and ponder how to establish a scientific and effective long-effect management mechanism for improvement of the quality of graduation design (paper).

\section{References}

[1] Shen Qi, Zhang Yan, Gu Qiuting. Design of quality control scheme of applied engineering graduation project [J]. Experimental technology and management, 2010, 27(12):167-170.

[2] Yang Zhujuan, Yang Xiaodong. Analysis of saving and abolishing of undergraduate graduation design (thesis) [J].Heilongjiang higher education research, 2011(9): $160 \sim 162$.

[3] Hou Xiaohua. Factors influencing the quality of undergraduate thesis and their monitoring [J]. Education academic journal, 2011(7): 62 63, 66.

[4] Ma Liang, Zhao Jinghua, Hong Ming. Selection of topics for undergraduate students majoring in agricultural water conservancy engineering and the role of sand table model in irrigated areas [J]. Experimental technology and management, 2015, 32(11):177-179.

[5] Chen Wenxiang. Research on progressive cultivation model of college students' academic paper writing [J]. Chinese university teaching, 2015(10):60-64+16.

[6] Ai Lingmei. Study on measures to improve the quality of computer graduation design in normal university [J]. Education theory and practice, 2012, 32(15):62-64.

[7] Miao Pengcheng. Research on influencing factors and countermeasures of undergraduate graduation design quality -- taking electronic information major in normal universities as an example [J]. Journal of shanxi normal university (social science edition), 2013, 40(S3):157-159.

[8] The general office of the ministry of education.Circular of the general office of the ministry of education on strengthening the graduation design (thesis) work of ordinary colleges and universities [Z]. [2004] no. 14, 2006.

[9] Du Yun, Li Zheng, Huang Gongfa, Zhao Yuyang. Teaching reform and practice of applied undergraduate instrument major graduation design [J]. Higher education journal, 2017(20):158-161.

[10] Education department. Notice on doing well the pre-job training for teachers in colleges and universities across the province in 2017 (su instructor [2017] no. 10)

[11] Zhong Guiying, Wu Qiaorong, Wang Wenbo. Construction of quality evaluation index system 
for higher vocational graduation design [J]. Professional technology education, 2010, 31(20):81-83. [12] Liu Bojie, Liu Zejun. Brief analysis of reasons and countermeasures of quality landslide in undergraduate graduation design (thesis) [J]. China higher education research, 2007(07):89-90.

[13] Ji Min, Ma Degang. Establishment of graduation design management system to improve the quality of graduation design [J]. Chinese university teaching, 2007(05):20-22.

[14] Wang Junyi. Undergraduate graduation design management and whole-process quality control [J]. Heilongjiang higher education research, 2006(04):84-85.

[15] National medium - and long-term program for reform and development (2010-2020) [N].People's Daily, 2010-07-30. 